\title{
Abstracts of Posters Presented at the Annual Meeting
}

\author{
Does Regulation Matter? An Analysis of Corporation Charters in A Laissez-Faire \\ Environment
}

Are laws that protect minority investors a necessary condition for the development of stock markets? This paper addresses this question using data on the origins of the corporate sector in Chile. The paper presents an empirical analysis of the contractual provisions included in corporate chargers from 1854 to 1902. The main finding is that, even though corporate law in Chile at the time was silent with respect to governance rules and investor protection, corporate charters substituted for this absence by including provisions favorable to outside investors. Moreover, the use of these contractual provisions in consistent with the predictions $\mathrm{f}$ an agency model. Minority investors had more rights in companies where capital requirements were higher, where investors were located far from the firm's productive activities, and where there were no alternative control mechanisms available.

GONZALO IsLas, University of California, Los Angeles

\section{Borders, Market Size, and Urban Growth}

Reductions in trade barriers have a potentially strong impact on economic development. The Zollverein, a customs union between German states initiated in 1834, erased borders in much of central Europe. This paper investigates the Zollverein's economic impact through a case study of urban population growth in Saxony during the nineteenth century. Using a model of the influence of market size on urban growth, I determine empirically the influence on growth of geographic position relative to borders and therefore domestic as well as foreign markets. I compute the relative positions of all Saxon towns using an improved distance measure based on GIS techniques. My measure takes into account elevation patterns, roads and rivers used for trade, as well as the role of rivers as obstacles for land routes. My results illustrate the relative roles of institutions (such as trade rules), transportation infrastructure development, and natural transportation endowments.

FLORIAN PlOECKL, Yale University

\section{Diversity, Religious Competition, and the Rise and Fall of Muslim Science}

The mechanisms by which heterogeneous societies channel between-group interactions towards productive ends remains poorly understood. Using medieval data from the thirteenth-century Levant, this paper argues that institutionalized tolerance is one such mechanism. The dhimmi institution, which guaranteed non-Muslims a (relatively) large degree of tolerance and religious freedom, created "religious competition" for converts and societal standing. Institutionalized tolerance, coupled with the initial theological and numerical superiority of Christians gave Muslim religious and political elites incentives to encourage the use of Aristotelian logic. Results suggest that as the societies under Muslim rule became increasingly (religiously) homogeneous, religious competition decreased, leading to a sharp decline in nonreligious intellectual enterprise. 


\section{The Beginning of the End: How Labor Markets Undermined Apartheid in South Africa}

One generally thinks of the 1980s as being the decade that culminated in the end of apartheid in South Africa. International political pressure and domestic civil unrest are credited with its downfall. I show that prior to these events, labor market pressure in the early 1970s caused a dramatic unraveling of apartheid in the workplace. The rapid growth of manufacturing industries place demands on labor that could not be met by existing supply. Coupled with a reduction in white resistance to black employment resulting from increased white education, these changes led to a massive restructuring of the manufacturing sector labor force by opening semi-skilled jobs to blacks and rapidly reducing the black-white wage gap. Using three different data sets, I show that the heavy goods industries drove the wage and employment increases; that whites were leaving semi-skilled manufacturing jobs; and that blacks were filling these jobs by the early 1970s.

MARTINE MARIOTTI, University of California, Los Angeles

\section{The Costs of Civil Wars: Micro Evidence from Chinese National Railroads, 1906-1923}

This article examines the impacts of numerous civil wars on 17 Chinese national railroads during the Later Qing and the Warload Periods (1906-1923). By incorporating wars as uncertainties into a firm's value maximization model, the results indicate: first, that civil wars had both contemporary and persistent negative impacts on business passenger and freight flows; second, that, on average, operating revenue and expense per $\mathrm{km}$ were reduced by 34 percent and 24 percent since a railroad experienced its first strife, respectively; third, that employment increased before and after the war; and finally, that, on the one hand, war affected investment decision through affecting managers' expectations of future profitability (Tobin's Q), and on the other hand, wars had a negative impact on the investment ratio, e.g., the destructive power of war threatened the management from more investment.

DAN LI, Boston University

\section{The Economic Role of Suburbs in the Low Countries in the Sixteenth Century}

The tension between urban guilds and the rural putting-out system in the early modern period has been well documented. However, this debate has ignored the role of the many suburbs, which sprang up outside city walls. This paper uses a unique set of surveys of suburban household composition and labor practices from the 1540s to evaluate the economic status of the suburbs, including the structure and stability of the work force, systems of training and apprenticeship, types of production, and the role of the household economy. The survey also provides detailed information on female workers and their involvement in household workshops. The suburbs functioned as a "third economy" between the urban and the rural systems. City authorities repeatedly expressed fears that suburban goods would subvert the urban guild system by offering unregulated products at lower prices. However, the goods produced in the suburbs were inexpensive and designed for the local market. As a result, they did not compete with the high-value export products of the Low Countries, such as textiles. The suburbs also provided an important source of cheap semi-skilled workers for urban workshops. 


\section{Natchez Merchants: Enterprise and Exploitation in the Postbellum South}

While economic scholars have addressed the economic role of the furnishing merchant in the postbellum South, no scholar has yet provided a detailed case study focused entirely upon the emergent merchant class that dominated the Southern agrarian economy. This research will reveal the economic and social impact of postwar merchants in a new, intensive way through examination of chattel mortgage, property, tax, probate, and chancery records contained in the Natchez District of Mississippi and Louisiana. In the EHA poster session I presented a visual representation of several elements of my preliminary dissertation research of the Natchez District mercantile class.

AARON ANDERSON, University of Southern Mississippi

\section{Economic Openness, Industrial Development, and Income Distribution in China, 1860-1936: Evidence from China Maritime Custom Archives}

China experienced drastic economic openness and industrialization from 1860s to 1936. However, little quantitative evidence has be collected to study the extents and impacts of these changes. This project estimates nominal wage series in nearly 50 Chinese cities from 1860 to 1936 using newly constructed Maritime Custom employees' wage data. It also constructs cost-of-living indices on the basis of raw prices and expenditure weights developed from custom trade statistics and surveys. The resulting nominal wage series and cost-of-living indices make it possible to estimate real income trends for different income groups of people and for different regions. The key findings are: real wages declined in the nineteenth century and began to grow in the 1920s; the skill premium increased rapidly before 1915 and declined afterwards; the regional gap increased rapidly before 1912 and declined afterwards. The thesis explores the factors that caused these gaps to widen and narrow, including technologydriven changes in the demand for different types of workers, the migration of people and jobs among regions, and increased investment in education in the early twentieth century.

SE YAN, University of California, Los Angeles

\section{Amartya Sen Revisited: Population, Production, and Inequality in Eighteenth-Century Guadalajara}

The study presents original series that have been collected in the historical diocesan archive of Sigüenza and that include baptismal records and cereal production for the province of Guadalajara during the eighteenth century. The research includes more than 200,000 observations from the individual producers and households. The main purpose of the paper consists in giving an answer to the demographic paradox that took place in the province of Guadalajara during the second half of the eighteenth century when population maintained a sustained and intense growth while the production of cereals was relatively constant and even declined. The main answer provided in the paper is based on a change in the production function of the small producers in the second half of the century that allowed a reduction in inequality levels and therefore a better distribution of income. 